\title{
量子カスケード・レーザーの雑音特性一分光応用を考慮してー
}

\author{
笠原 健一 \\ 立命館大学 理工学部電子光情報工学科 (†525-8577 滋賀県草津市野路東1-1-1)
}

\section{Noise Properties of Quantum Cascade Lasers for Spectroscopic Applications}

\author{
Kenichi KASAHARA \\ Department of Photonics, Faculty of Science and Engineering, Ritsumeikan University, \\ 1-1-1 Noji-higashi, Kusatsu, Shiga 525-8577
}

(Received June 22, 2011)

\begin{abstract}
Quantum cascade lasers (QCLs) have become useful light sources in the mid- to far-infrared wavelength ranges because they employ intersubband transitions. This results in phase and intensity noise properties different from those of conventional semiconductor laser diodes that are based on interband transitions. It is important to investigate noise-related characteristics of QCLs for spectroscopic applications. We have investigated the intensity noise and optical feedback-induced noise. It was found that QCLs are more tolerant of optical feedback than semiconductor laser diodes due to a long cavity length and a small linewidth enhancement factor. This factor broadens the fundamental linewidth of QCLs, determined by the phase noise, limiting the spectral resolution. Although the linewidth enhancement factor of QCLs should be small in principle, until now, only a limited number of experimental data have been reported above the threshold. We measured the linewidth enhancement factor of QCLs in detail and performed a quantitative analysis of the experimental results.
\end{abstract}

Key Words: Quantum cascade laser, Relative intensity noise, Optical feedback-induced noise, Phase noise, Linewidth enhancement factor

1.はじめに

サブバンド遷移を使って発振する量子カスケード・ レーザー(Quantum Cascade Laser: QCL)の研究開発は欧 米を中心に活発に行われている. 中赤外域でのQCLは室 温動作が実現され, 環境モニタや半導体プロセス, 食品 製造時のガス計測, エンジンの燃焼診断, 薬品や爆発物 の発見, 個人向けの医療診断, 生命科学への応用が考元 られている。米国では軍事面から安全を脅かす化学的, 生物学的媒介物の検知や秘話通信での応用も考えられて いる。 大気中の塵などによるレイリー散乱は波長の4乗 に反比例する。したがって中赤外光のレイリー散乱は可 視光に比べて小さくなり，QCLを使ったレーダや測距,

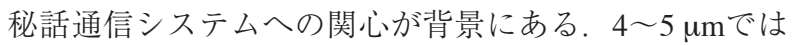
$\mathrm{CO}_{2}, \mathrm{CO}$ の吸収があり環境計測や排ガス分析によるエン ジン開発，呼気診断への応用が期待されている． $5.2 \mu \mathrm{m}$ ではNOの吸収があるが，NOは循環器系における信号伝 達物質の役割を果たしており，分子イメージングなど生 体計測への応用も期待されている. $\mathrm{NO}_{2}$ の吸収は6.1 $\mu \mathrm{m}$ にあってエンジン開発や環境計測の対象となる。また $\mathrm{SO}_{2}$ の吸収は7.4 $\mu \mathrm{m}$ にある. $9.5 \mu \mathrm{m}$ 近傍ではグルコース のセンシングなどが挙げられる. 分光応用であるので基
本的にQCLの波長をチューニングする必要がある。それ には，1)Distributed feedback(DFB)-QCLを例えばデュ ワーなどに入れ，温度を変えて波長をチューニングす る，2)DFB-QCLに数100 nsのパルスを印加し，熱的に温 度が上昇することを使って波長を時間的にシフトさせ る，3)外部共振器形として回折格子を使って波長を変え るといった方法が用いられている. 外部共振器形を使う 方法では波長可変幅は中心波長〜2,260 $\mathrm{cm}^{-1}(4.4 \mu \mathrm{m})$ で $\mathrm{cw}$ 動作時の可変幅が $121 \mathrm{~cm}^{-1}$ と大きな值が得られている ${ }^{1)}$. 線幅は $0.0015 \mathrm{~cm}^{-1}(45 \mathrm{MHz})$ である。パルス動作での可 変幅は $525 \mathrm{~cm}^{-1}$ と更に拡大する。活性層は離散準位とミ ニバンド間の遷移を使い，更にこれを段間で変えること で利得幅を広げる事も行われている。

このようなQCLの分光応用ではQCLの雑音特性を把握 しておく事が大切である。 QCLはサブバンド間遷移を 使って発振するのでバンド間遷移を使った半導体レー ザー・ダイオード (Laser diode: LD) とは異なる強度雑音 特性を示す。また中赤外域では良い光アイソレーターが 無いのでレーザー固有の雑音に加えて戻り光誘起雑音に ついても十分な理解が必要である。一方, 位相雑音は QCLのスペクトル幅に影響を及ぼす。分光応用では分解 能の点からレーザーのスペクトル幅が狭い事が望まし 
い. $1.5 \mu \mathrm{m}$ 帯の半導体LDでは第2高調波を $\mathrm{Rb}$ の吸収線に ロックすることで発振周波数の安定化が報告されている が2)，QCLでも8.5 $\mu \mathrm{m}$ 帯で $\mathrm{N}_{2} \mathrm{O}$ の振動回転準位にロック することで周波数の安定化が試みられている。 その結果 からQCLのスペクトル幅として $12 \mathrm{kHz}$ と狭い值が推測さ れている ${ }^{3)}$. 半導体LDの発振線幅は線幅増大係数 $(\alpha$ パ ラメータ)によって広がるが, QCLでも同様な事が起 こっているものと考えられる。QCLはサブバンド間遷移 によって発振するので原理的に $\alpha$ パラメータは〜 0 と小 さくなるはずであるが，発振波長が利得ピークからずれ た時にどのように変わるか余り知られていない， $\alpha$ パラ メータはまた利得形状に密接に結びついているので, 測 定を通じてQCLの低電流化に対する知見を得ることが出 来る，本稿では実用化が進んでいる中赤外QCLの雑音特 性の強度雑音や戻り光誘起雑音特性, パラメータを中心 に述べる。

\section{2. 量子カスケード・レーザーの強度雑音}

強度雑音は以下のような相対雑音強度 (RIN: Relative intensity noise)で評価される. RINは光出力の時間変動の 二乗平均 $\left\langle\delta P^{2}\right\rangle$ を平均光出力 $P$ で割った值で定義され, スペクトル・アナライザーを使った測定では以下の式か ら求めることができる

$$
\operatorname{RIN}(\omega)=S_{\mathrm{P}}(\omega) / B G I_{\mathrm{ph}}^{2} R
$$

式 $(1)$ で $S_{\mathrm{p}}(\omega)$ はスペクトル・アナライザー上で観測さ れるQCLのAC雑音電力，Bはスペクトル・アナライザー の分解能, $G$ は用いるアンプの電力利得, $I_{\mathrm{ph}}$ は受光素子 に流れる光 $\mathrm{DC}$ 電流, $R$ はアンプの入力インピーダンスで この場合 $50 \Omega$ あ゙あ. 相対雑音強度はRIN $\propto P^{-\gamma}$ といっ た形で表すことができ, $\gamma$ 電流依存性を調べることで QCL固有の雑音発生メカニズムに対する知見が得られ る. QCLの強度雑音特性についての報告は我々の所から の報告も含めて少なく測定は77 Kであった ${ }^{4,5)} .5 .1 \mu \mathrm{m}$ DFB-QCLを用いた測定では規格化電流を $a=I_{\mathrm{in}} / I_{\mathrm{th}}-1$ $\left(I\right.$ : 電流, $I_{\mathrm{th}}$ ：しきい值電流 $)$ とすると, $\gamma \approx 2.7(0.01$ $<a<0.05), \quad \gamma \approx 2.3(0.08<a<0.15), \quad \gamma \approx 1.8$

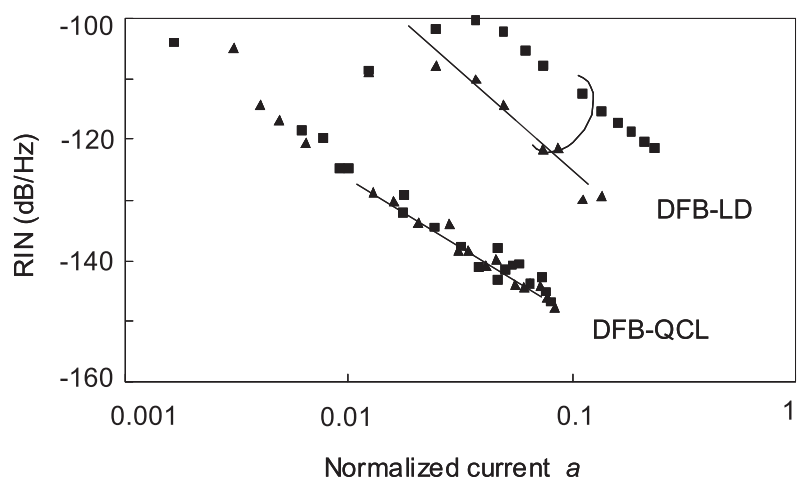

Fig. 1 RIN of DFB-QCL and DFB-LD. $\mathbf{\Delta}$ : without optical feedback, $\square$ : with optical feedback, Distance between QCL output mirror and external mirror, $L=$ $60 \mathrm{~cm}$. $(0.49<a<0.5)$ といった值が得られている ${ }^{5)}$. 室温付近 でのRINはSPC (Single Phonon-Continuum depopulation structures)構造を持つ6.1 $\mu \mathrm{m}$ DFB-QCLを用いて測定した (Fig. 1).SPC構造ではレーザー下側準位の下方にLO フォノンと同程度のエネルギー位置に電子を引き抜くた めの緩和準位が作られている。そして，更にその下方に 疑似連続準位が形成されていることで安定な室温cw動 作が実現される ${ }^{6)}$. 本QCLはペルチェ素子で動作温度が

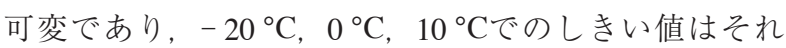
ぞれ417 mA， $476 \mathrm{~mA}, 509 \mathrm{~mA}$ でる。受光素子には InSb光導電型受光素子 (Photoconductive detector: PCD, P6606-305）を用いた。受光感度は2500 V/W，最大感度 波長5.5 $\mu \mathrm{m}$, 長波長側カットオフ波長 $6.3 \mu \mathrm{m}$, 暗抵抗 $101 \Omega$ (ペルチェ電流300 mA時)であり, 受光径は $0.5 \mathrm{~mm} \times 0.5 \mathrm{~mm}$ である。杂隹音のAC成分は利得 $40 \mathrm{~dB}$ の低 雑音アンプ $(\mathrm{NF}, \mathrm{BX}-31 \mathrm{~A})$ で増幅した後, スペクトル・ アナライザー (Agilent, N1996A) で観測した。受光素子 の $3 \mathrm{~dB}$ ダウン周波数は $3 \mathrm{MHz}$ あ゙り, 雑音電力は

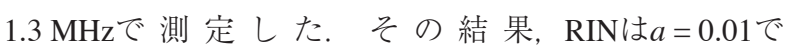
$-125 \mathrm{~dB} / \mathrm{Hz}, \quad a=0.08$ で $-147 \mathrm{~dB} / \mathrm{Hz}$ であった。 また $\gamma \approx 2.2(0.01<a<0.08)$ であった(Fig. 1). 一方, DFB-LD では $\gamma \approx 3.0(0.03<a<0.1)$ となり，QCLとは異なる，こ の違いはQCLでは自然放出光による通常の雑音発生メカ ニズムの他に，電子のサブバンド内非発光緩和に伴う反 転分布の摇らぎが生ずるためである ${ }^{4)}$ ，通常のバンド間 遷移を使った半導体LDでは自然放出光による雑音がし きい值近傍で大きくなり, $\gamma$ は理論的に 3 となる。電流が 増大するとショット雑音が主となって $\gamma$ は1に近づく。そ れに対してQCLではサブバンド間遷移を使い，電子の緩 和速度がpsオーダーと高速であることから反転分布の摇 らぎが無視できなくなる。そのためにバンド間遷移を 使ったLDとは $\gamma$ の振る舞いが異なってくる， $\gamma$ の光出力 依存性は段数によって変わるが, 段数が多いほどの $a$ の 小さい段階から電子分布の摇らぎの影響が出てくる，中 赤外域のQCLでは電子注入層/発光層は一般的に〜30段 から成るが, 計算によればこの位の段数では $a$ は 0.01 と 0.1 の間で $\gamma \approx 2$ となり，測定結果とほぼ一致する。

Fig. 1には戻り光がある場合の雑音特性も示してあ る、QCLでは線幅が狭く、コヒーレンシーが高いので戻 り光によって雑音が大きく発生するのではないかといっ た懸念があった。それを調べるためにDFB-QCLからの 出力光を無反射 $(\mathrm{AR})$ コートしたレンズでコリメートし, 50\% : 50\%ビーム・スプリッターで2分岐させた ${ }^{7)}$ 。一方 の光は $\mathrm{Al}$ 外部ミラーで反射させてQCLに戻し，もう一方 はARコート・レンズを通しPCDに集光した．Fig. 1には $\mathrm{QCL}$ の出力ミラーから外部ミラーまでの距離 $L$ ミ゙ $60 \mathrm{~cm}$ の場合での結果を示してあるが, 戻り光の有無による RINの大きな変化は観測されなかった。比較のために $1.5 \mu \mathrm{m}-\mathrm{DFB}-\mathrm{LD}$ の場合も調べた。測定系は, ARコート 波長を $1.5 \mu \mathrm{m}$ とし，受光素子にpin-PDを用いた点を除い てQCLと同様な配置とした。 DFB-LDのRINは規格化電 流が 0.04 では約 $10 \mathrm{~dB}, 0.10$ 時は $17 \mathrm{~dB}$ と戻り光が有る事 によって増大した。ファブリ・ペロー干渉計を用いてス 
ペクトルを観測すると，戻り光が有る時はスペクトルが 広がってコヒーレント・コラプスが生じている事が確認 できた.コヒーレント・コラプスは戻り光によるレー ザーの発振周波数の変化が緩和振動周波数に近づくと起 こる. 発振周波数の変化は $\sqrt{1+\alpha^{2}}\left(\sqrt{R_{\text {ext }}} / l\right)$ に比例する。 ここで $R_{\mathrm{e}}$ は外部ミラーの実効的な反射率(i.e. 戻り光の レーザー活性層への結合効率まで含めた反射率)， は共 振器長であり， $R_{\mathrm{ext}}$ が同じならば $\alpha$ 小さく， 仿大きい ほど発振周波数の变化量は緩和振動周波数に近づかな い.つまり戻り光によるコヒーレント・コラプスは起こ りにくくなるはずである ${ }^{8)}$. 測定に用いたDFB-LDでは $\alpha=6.0, L=0.3 \mathrm{~mm}$ であるのに対し, QCLでは $\alpha=-1.8$, $L=2 \mathrm{~mm}$ であった．そのためQCLのコヒーレント・コラ プスが起こる戻り光レベルはDFB-LDよりも計算上20倍 ほど高くなるはずであり, Fig. 10結果はこの事を反映 しているものと考えられる. QCLの線幅増大係数 $\alpha$ が DFB-LDと比べて小さく, 更に共振器長が長い事は戻り 光誘起雑音の抑制に対して一般的に有利に働き, 分光応 用上, 都合が良い.

RINの計算では各発光層からの雑音発生が同時に起こ る事を仮定している，QCL内の発光層は直列につながっ て電流が流れる，したがって一つの発光層で光子発生の 変動が生じるとそれが他の発光層での光子発生を引き起 こすと考えられる。しかしながら厳密に考えると話はや や複雑となり, 各発光層からの光子発生の相関は発光層 のインピーダンスや外部電源のインピーダンスによるこ とが指摘されている ${ }^{5}$. 電源として定電流源と定電圧源 を用いた場合, 前者の方が雑音は小さくなる事が予想さ れ，RINがどれくらい変わるのか実際に調べてみた。し かしながら測定の範囲内では両者に明確な差異は観測さ れなかった，実際の定電流源で定電流動作が保証される のは〜 ms以上の電流変動であって, それより高速の変 化には一定電流動作が追いつかない，こういった点が違 いが観測されなかった理由の一つとしてあるのではない かと考えている.

\section{3. 量子カスケード・レーザーの線幅増大係数}

\section{1 線幅増大係数}

QCLの分光学的応用ではスペクトル線幅は狭いことが 望ましい. 半導体LDではキャリア密度の変化に伴い, 光学利得や屈折率の变化がおこる, 定常電流状態での発 振の線幅は, Schawlow-Townesの線幅に対して $\left(1+\alpha^{2}\right)$ 倍に広がる. 半導体LDの共振起内のキャリア密度を $N$ と し, 電気感受率の実部, 虚部をそれぞれ $\chi_{\mathrm{R}}, \chi_{\mathrm{I}}$, 屈折率 と利得のキャリア密度 $N$ の変化に対する変動を $\Delta n, \Delta g$, 波長を入とすると $\alpha$ は式(2)で求められる.

$$
\alpha=\frac{\partial \chi_{\mathrm{R}}}{\partial N} / \frac{\partial \chi_{\mathrm{I}}}{\partial N}=-\frac{4 \pi}{\lambda} \frac{\Delta n}{\Delta g}
$$

通常のLDでは曲率の符号や大きさも異なる伝導体と 価電子帯の間で電子が遷移するため, 利得分布はピーク 波長に対して非対称となる。 そのために利得ピークで $\alpha$
はゼロとならない。実際に1.5 $\mu \mathrm{m}-\mathrm{LD}$ を使った測定から は $\alpha=2 \sim 70$ 值が報告されている。一方，QCLでは曲率 の符号と大きさの等しいサブバンド間で遷移が起こるの で利得分布は左右対称となり， $\alpha$ は利得ピークでゼロと なる. QCLの $\alpha$ 值の測 定 はHakki-Paoli法 ${ }^{10)}$ やOpticalHeterodyne 法 $^{11)}$, Self-Mixing法 (以下SM法と略記する) ${ }^{12)}$ によって求められているが報告例は多くない。これらの 内でHakki-Paoli法は原理的にしきい值近くでの $\alpha$ 值しか 求められない. またOptical-Heterodyne法は発振周波数の 近いQCLを2個，用意せねばならず，測定が容易でな い.それに対してSM法ではしきい值以上の $\alpha$ を測定す ることが出来る上, 測定系も簡易に構成することができ

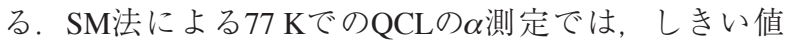
付近で $\alpha=-0.44 て ゙ あ り, ~ \alpha$ は電流上昇と共に増加するこ とが報告されているが理由ははっきりしていない.また 実際のQCLでは発振波長は必ずしも利得ピークにあるわ けでなく，デチューニングによって $\alpha$ ぞどのように変化 するのか分かっていなかった。 そこで，我々はSM法を 室温cw動作可能なQCL等に適用して $\alpha$ の精密測定を行っ

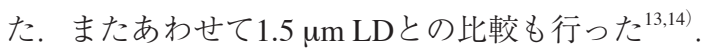

\section{$3.2 \mathrm{SM}$ 法を用いた $\alpha$ の測定系}

測定で用いたSelf-Mixing法の実験系をFig. 2に示す.

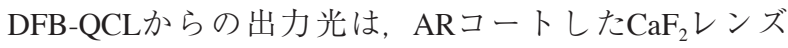
(焦点距離： $8.5 \mathrm{~mm}$, 口径 $8.0 \mathrm{~mm}$ )を用いてコリメート し，外部ミラーに入射させた．外部ミラーはアクチュ エーターに固定されており, 出力光波形の検出は電圧の 変動から測定する手法をとった ${ }^{12)}$ ，当初はこの部分にピ エゾ素子を用いたが変位量が少なく, 電気的な雑音を拾 うという問題があったが，ボイス・コイルに変える事で 測定は改善された。戻り光によるキャリア密度の変化は 光出力の変動を引き起こし, それに比例した電流の変化 をもたらす．光出力を検知する方法では外部にハーフ・ ミラーをいれて出力光の一部を受光素子で検出する必要 がある，そのために，元々微弱な信号がさらに弱くな り。また光学的なアライメントも必要となって複雑にな る。それに対して, 電流変化を抵抗を介して電圧で検出 する方法は測定が簡単にできるというメリットがある. 電圧の微少変動は結合用のコンデンサを介して取り出

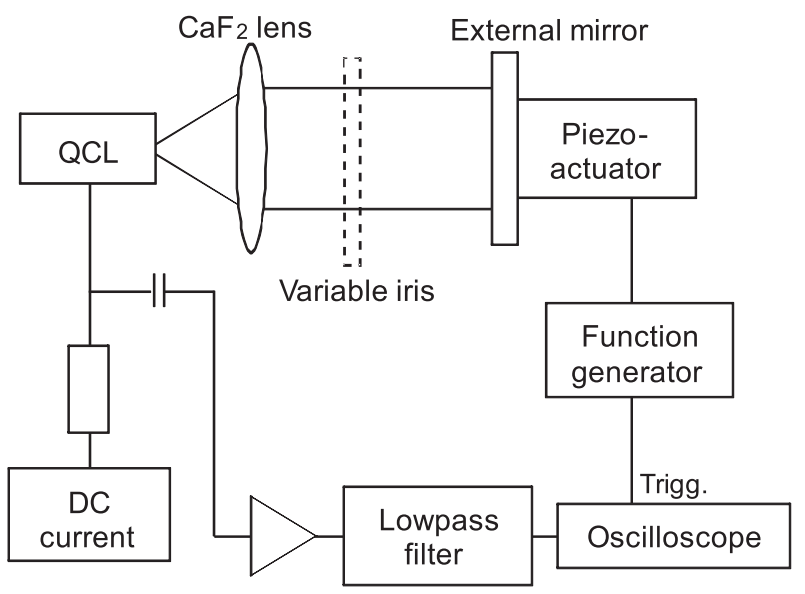

Fig. 2 Experimental setup for measuring $\alpha$-parameter. 
し, FETアンプ (40dB, Noise Figure: $0.8 \mathrm{nV} / \mathrm{Hz})$ で増幅さ せた。アンプの帯域は $200 \mathrm{kHz}$ であり，不要な高周波ノ イズを除去するために $25 \mathrm{kHz}$ のローパス・フィルタを挿 入し，オシロスコープで波形を観測した。

\section{3 測定結果}

SM法ではレーザーから出力された光は外部ミラーに よって反射され, 再びレーザーに戻る。 この時, 共振器 内の位相と外部共振器の位相の違いから, レーザー内部 のキャリア密度が変化し, 出力光が変動する. そのた め, 外部ミラーを周期的に振動させると出力光には特徵 的な波形が現れる。この戻り光状態でのレーザーの振る 舞いは覧具・小林によって解析され，変調波形は次式に 示すように， $\alpha$ と戻り光の強度に関係するフィードバッ ク・パラメータCによって決められる ${ }^{15,16)}$.

$$
\begin{gathered}
P=P_{0}[1+m \cdot \cos (\phi)] \\
\phi=\phi_{0}-C \sin [\phi+\arctan (\alpha)] \\
C=\frac{L \sqrt{1+\alpha^{2}}}{n l}(1-R) \sqrt{\frac{R_{\mathrm{ext}}}{R}}
\end{gathered}
$$

ここで $P, \phi$ は戻り光がある場合の光出力と位相, $P_{0}$, $\phi_{0}$ は戻り光がない場合の光出力と位相である。また $m$ は 変調度を表す。Rはレーザーの出力ミラーの反射率, $R_{\mathrm{ext}}$ は先に述べた外部ミラーの実効反射率，nはレーザー媒 質の屈折率である。 $\alpha$ が小さと $C<1$ となり，その時に はFig. 3のような波形が得られる. Fig. 3に示されている ように観測波形から $X_{\mathrm{Z}}, X_{\mathrm{M}}$ を定義すると $\alpha, C$ は下の ように求めることができる.

$$
\alpha=\frac{X_{\mathrm{M}}-0.5}{X_{\mathrm{Z}}-0.5}
$$

$$
C=\pi\left(X_{\mathrm{Z}}-0.5\right) \sqrt{1+\left(\frac{X_{\mathrm{M}}-0.5}{X_{\mathrm{Z}}-0.5}\right)^{2}}
$$

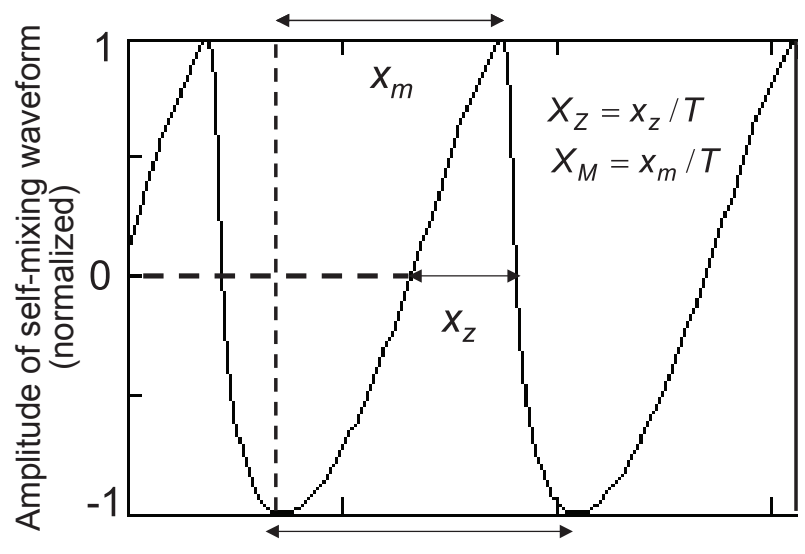

$T$

Fig. 3 Self-mixing waveform of a 6.1-um DFB-QCL observed at $570 \mathrm{~mA}$ at $253 \mathrm{~K}$. The voltage applied to a Piezo-actuator and the self-mixing signal were fed to the horizontal and vertical input of an oscilloscope, respectively. The definitions of $X_{\mathrm{Z}}$ and $X_{\mathrm{M}}$ are shown in the figure. $\alpha$ and $C$ were determined to be -1.7 and 0.86 , respectively, from the waveform.
Fig. 3の波形は6.1 $\mu \mathrm{m}$ DFB-QCLの $570 \mathrm{~mA}, 253 \mathrm{~K}$ の時の 結果であるが, この場合， $\alpha=-1.7, C=0.86$ と決定さ れる. Fig. 4はQCLの $\alpha$ の電流依存性を示したものであ る。測定した範囲内では $\alpha$ は電流の増大と共に緩やかに 増大する傾向を示した。式(5)よりCを $\sqrt{1+\alpha^{2}}$ で割った 值 $(=\beta)$ はQCLに流れる電流に依らず一定となるはずで あり, Fig. 4には $\beta$ の值も示してある.

Fig. 5 (a)には77 Kでの5 $\mu \mathrm{m}$ DFB-QCL（しきい值電流 $290 \mathrm{~mA}$ )の315 mAの時の波形を示してある。このQCLで は電流を上げていくと発振波長が〜 $5.15 \mu \mathrm{m}$ から

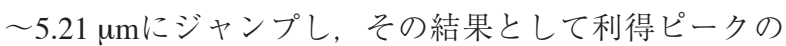
両側での $\alpha$ 值が測定できる. Fig. 5 (a)の発振波長は $5.15 \mu \mathrm{m}$ であり, $\alpha=-1.5, C=1.5$ と決定できるが. そ の場合の計算波形をFig. 5 (b) に示してある. 電流が $400 \mathrm{~mA}$ では発振波長は5.21 $\mu \mathrm{m}$ にジャンプし, その時は $\alpha=0$ 0.5であった。 $315 \mathrm{~mA}$ では発振モードは利得ピー

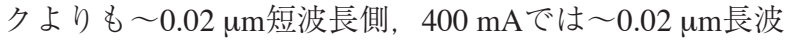

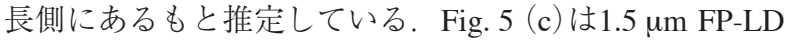
（しきい值電流 $10 \mathrm{~mA}$, 動作電流 $18 \mathrm{~mA}$ )のSM波形である が，QCLと異なるノコギリ波状の波形が観測された。

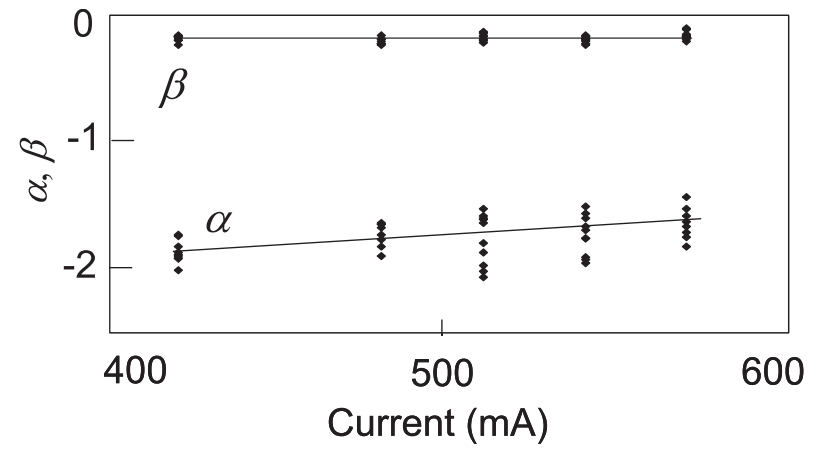

Fig. $4 \alpha$ and $\beta$ dependences on current of a 6.1- $\mu$ m DFBQCL at $253 \mathrm{~K}$. $\beta$ is defined by $C / \sqrt{1+\alpha^{2}}$. $\beta$ should not vary even if the current varies.

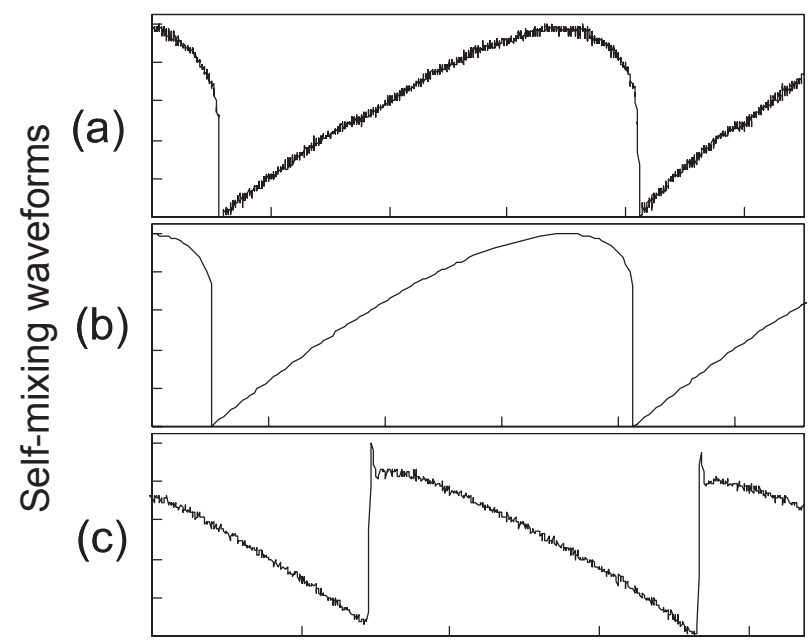

Time (s)

Fig. 5 (a) Self-mixing waveforms observed for a $5 \mu \mathrm{m}$ DFB-QCL at $315 \mathrm{~mA}$, (b) Calculated waveform: $\alpha=-1.5, C=1.5$. (c) Self-mixing waveforms observed for a $1.5 \mu \mathrm{m}$ FP-LD at $18 \mathrm{~mA}$. Horizontal: (a) $1 \mathrm{~ms} / \mathrm{div}$ and (c) $0.8 \mathrm{~ms} / \mathrm{div}$. 
$|\alpha|>1, C>1$ の時には計算上，このような波形となるは ずであり，波形の傾く方向も考慮すると $\alpha=6 \sim 7$ となる.

\subsection{QCLの利得形状と $\alpha$ パラメータ}

QCLの $\alpha$ 值の測定結果はゼロからずれており, サブバ ンドで放物線や弾性散乱を伴った電子遷移等の影響も含 めて検討する必要がある。簡単のために発光層が単一量 子井戸から成る場合を考えるとQCLの利得は以下のよう に表すことができる ${ }^{17,18)}$

$$
\begin{gathered}
g(\Omega)=\frac{4 e^{2}\left|z_{12}\right|^{2} m_{\mathrm{e}} \Omega}{\pi \hbar^{3} w c \sqrt{\kappa_{\infty}}} \int_{0}^{\infty}\left(\frac{\gamma_{\mathrm{k}}\left(f_{2}-f_{1}\right)}{\left(\Omega-\Omega_{\varepsilon}\right)^{2}+\gamma^{2}}+\right. \\
\left.\frac{\gamma_{\mathrm{k} 1}\left(f_{2}-f_{11}\right)-\gamma_{\mathrm{k} 2}\left(f_{1}-f_{22}\right)}{\left(\Omega-\Omega_{\varepsilon}\right)^{2}+\gamma^{2}}\right) d \varepsilon
\end{gathered}
$$

ここで囚は発振周波数, $\Omega_{\varepsilon}$ はFig. 5 の図中に示した $\varepsilon$ (上側サブバンドの底部から測ったエネルギー)に対応す る周波数, $e$ は電子電荷量, $z_{12}$ はダイポール・モーメン 卜, $m_{\mathrm{e}}$ は電子の有効質量, $\hbar$ はプランク定数, $w$ は量子 井戸幅, $c$ は光速, $\kappa_{\infty}$ は比誘電率, $\gamma_{\mathrm{k}}, \gamma_{\mathrm{k} 1}, \gamma_{\mathrm{k} 2}$ は緩和速 度でLOフォノンによる散乱のみを考慮すると階段状の 関数になる. 式 $(8)$ の右辺の積分の中の第1項はエネル ギー保存則によって決まる通常の垂直な遷移による利得 を表しており， $f_{2}, f_{1}$ はそれぞれレーザー上側準位，下 側準位の電子分布関数である。第2項は電子の弾性散乱 を伴った電子遷移(いわゆるブロッホ利得)を表してい る $^{12,13)}$. 反転分布が生じ始める辺りでは $f_{2}>f_{11}, f_{1}>f_{22}$ と なっている(Fig. 6). そのために第2項によってサブバン ド間波長よりも長波長側では正の利得，短波長側では負 の利得 (i.e.吸収) が生ずる。このような分散的な利得特 性は実験的にも示されている ${ }^{19,20)}$ 。一方，量子井戸内の サブバンドで放物線近似が成立するのは波数の小さい範 囲だけである。また各サブバンドの曲率も実際には異な る。そこでサブバンドの非放物線性をKaneモデルを使 い, サブバンドでの電子の有効質量の違いを入れて利得 を計算した，Kaneモデルでは $n$ 番目のサブバンドの底部

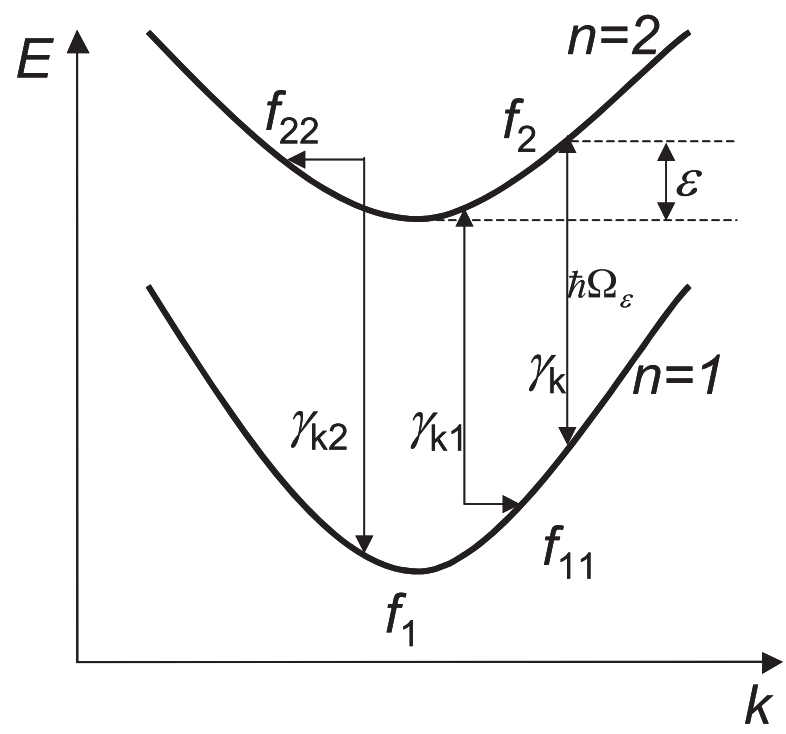

Fig. 6 Direct and scattering-assisted transitions between subbands with conduction band non-parabolicity.

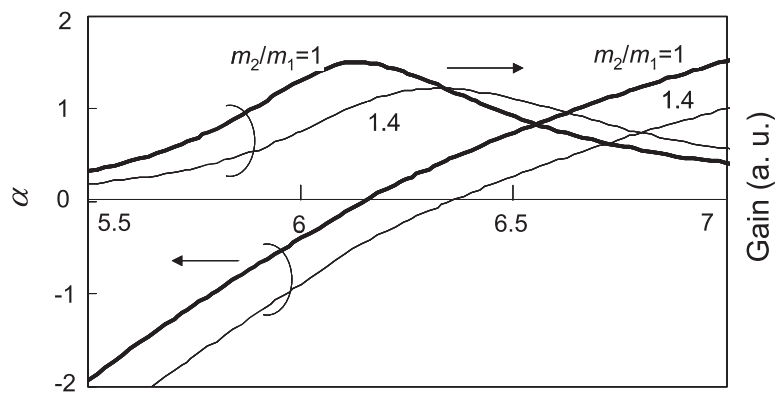

Wavelength $(\mu \mathrm{m})$

Fig. 7 Calculated gain and $\alpha$ as a function of the wavelength. Chip temperature: $290 \mathrm{~K}$. Electron sheet density of the upper subband: $2 \times 10^{9} \mathrm{~cm}^{-2}$, the lower subband: $1 \times 10^{9} \mathrm{~cm}^{-2}$. $\gamma$ was estimated from the spectrum broadening of electroluminescence of $\sim 18 \mathrm{meV}$.

における有効質量 $m_{\mathrm{n}}$ は式(9)のように近似できる.

$$
m_{\mathrm{n}}=m_{\mathrm{e}}\left(1+\frac{\pi^{2} \hbar^{2} n^{2}}{m_{\mathrm{e}} E_{\mathrm{G}}}\right)
$$

$E_{\mathrm{G}}$ はバンドギャップ・エネルギーで, $\mathrm{In}_{0.53} \mathrm{Ga}_{0.47} \mathrm{As}$ は準位間のエネルギー差を $200 \mathrm{meV}(\sim 6.1 \mu \mathrm{m})$ とした 時, $E_{1}=67 \mathrm{meV}, E_{2}=270 \mathrm{meV}, m_{1}=0.047 m_{\mathrm{e}}$, $m_{2}=0.067 m_{\mathrm{e}}\left(m_{2} / m_{1}=1.4\right)$ となる. 電子は上側準位にのみ 注入され，二つのサブバンドの電子温度は同じでボルツ マン分布をしていると仮定して計算を行った。上下のサ ブバンドの有効質量が等しく，電子密度が等しい時 (i.e.透明になる時) には通常の1次の遷移からは利得は生 じない。しかし，式(8)の第2項によって遷移波長よりも 長波長側では利得が，また短波長側では吸収が現れる. 電子密度の比が大きくなると通常の1次の遷移の影響が 強くなって, このような利得/吸収の非対称性は相対的 に消失していく，一方，非放物線性の影響を考慮する と, 電子密度が等しい時には第2項だけでなく 1 次の遷移 からも分散的な波形が現れる。電子密度の差を大きくす ると 1 次の遷移過程が主となり, 通常使用するしきい值 よりも大きな電流領域では利得の非対称性はサブバンド の非放物線性から現れてくる.

$\alpha$ を求めるには電気感受率の実部 $\chi_{\mathrm{R}}$ 求める必要があ るが、これは計算した利得からKramers-Kronigの関係を 使って求めることができる。通常のLDとは異なり，発 振後のQCLの電子密度は上側・下側準位ともに同じ量で 増加し続ける。このため, 計算では各準位の電子密度を 上側・下側とも同量だけ微少に変化させ，そのときの差 分から $\alpha$ を求めた (Fig. 7). $m_{2} / m_{1}=1.4 て ゙ は m_{2} / m_{1}=1$ に対 して利得のピーク波長は長波長側にシフトする。どちら の場合も発振波長が短波長から長波長に動くにしたがっ て $\alpha$ は負から正に変化するが， $1.5 \mu \mathrm{m}$ DFB-LDで観測さ れたような6といった大きな值は取らないことが分か る。デチューニングに伴う $\alpha$ の変化は大筋では測定結果 と合っているが，完全には一致しておらず，使用したモ デルの一層の精密化が必要である。 


\section{4. むすび}

中赤外QCLの分光応用に絡んで強度雑音や戻り光誘起 雑音特性，スペクトル幅に関わる $\alpha$ パラメータについて 述べた，QCLではバンド間遷移を使った半導体LDより も $\alpha$ パラメータが小さくなること等から戻り光誘起雑音 を抑制し，スペクトル幅も狭くできるといったメリット がある。中赤外域のQCLは室温CW動作化が達成され, $77 \mathrm{~K}$ に比べれば扱いも簡単にできるようになった。また 入手も比較的容易となっている，商業ベースでの応用も 一部, 開始されており，これらの特徵を活かした応用が 更に拡大されていくものと思われる。

\section{参考文献}

1) M. J. Weida, D. Caffey, J. A. Rowlette, D. F. Arnone, and T. Day: Opt. Eng. 49 (2010) 111120

2) A. Bruner, V. Mahal, I. Kiryuschev, A. Arie, M.A. Arbore, and M. M. Fejer: Appl. Opt. 37 (1998) 6410.

3) R. M. Williams, J. F. Kelly, J. S. Hartman, S. W. Sharpe, M. S. Taubman, J. L. Hall, F. Capasso, C. Gmachl, D. L. Sivco, J. N. Baillargeon, and A. Y. Cho: Opt. Lett. 24 (1999) 1844.

4) T. Gensty and W. Elsäßer: Opt. Express 13 (2005) 2032.

5) Y. Takagi, N. Kumazaki, M.Ishihara, K. Kasahara, A. Sugiyama, N. Akikusa, and T. Edamura: Electron. Lett. 44 (2008) 860.

6) K. Fujita, S. Furuta, A. Sugiyama, T. Ochiai, T. Edamura, N. Akikusa, M. Yamanishi, and H. Kan: Appl. Phys. Lett. 91 (2007)
141121.

7) T. Inoue, K. Tsushima, T. Kataoka, K. Kasahara, N. Akikusa, K. Fujita, and T. Edamura: To be presented in the 2011 Conference on Lasers and Electro-Optics (CLEO) Pacific Rim, Sydney, Australia.

8) R. W. Tkach and A. R. Chraplyvy: J. Lightwave Technol. LT-4 (1986) 1655.

9) F. Rana and R. J. Ram: Phys. Rev. B 65 (2002) 125313.

10) J. Kim, M. Lerttamrab, S. L. Chuang, C. Gmachl, D. L. Sivco, F. Capasso, and A. Y. Cho: IEEE J. Quantum Electron. QE-40 (2004) 1663

11) T. Aellen, R. Maulini, R. Terazzi, N. Hoyler, M. Giovannini, J. Faist, S. Blaser, and L. Hvozdara: Appl. Phys. Lett. 89 (2006) 091121.

12) J. V. Staden, T. Gensty, W. Elsäßer, G. Giuliani, and C. Mann: Opt. Lett. 31 (2006) 2574.

13) N. Kumazaki, Y. Takagi, M.Ishihara, K. Kasahara, A. Sugiyama, N. Akikusa, and T. Edamura: Appl. Phys. Lett. 92 (2008) 121104.

14) M. Ishihara, T. Morimoto, S. Furuta, K. Kasahara, N. Akikusa, K. Fujita, and T. Edamura: Electron. Lett. 45 (2009) 1168.

15) R. Lang and K. Kobayashi: IEEE J. Quantum Electron. QE-16 (1980) 347.

16) G. A. Acket, D. Lenstra, A. J. Den Boef, and B.H. Verbeek: IEEE J. Quantum Electron. QE-20 (1984) 1163.

17) V. B. Gorfinkel, S. Luryi, and B. Gelmont: IEEE J. Quantum Electron. 32 (1996) 1995.

18) H. Willenberg, G. H. Döhler, and J. Faist: Phys. Rev. B 67 (2003) 085315.

19) R. Terazzi, T. Gresch, M. Giovannini, N. Hoyler, N. Sekine, and J. Faist: Nature Phys. 3 (2007) 329.

20) D. G. Revin, M. R. Soulby, J. W. Cockburn, Q. Yang, C. Manz, and J. Wagner: Appl. Phys. Lett. 92 (2008) 081110. 